\title{
Harvest time on the content and chemical composition of essential oil from leaves of guava
}

\author{
Horário de coleta sobre o teor e a composição química \\ do óleo essencial das folhas de goiabeira
}

\author{
Elizabeth Aparecida Josefi da Silva ${ }^{*}$ Vanessa Paula da Silva \\ Cassia Cristina Fernandes Alves ${ }^{I}$ José Milton Alves $^{I}$ \\ Edson Luiz Souchie ${ }^{I}$ Luiz Cláudio de Almeida Barbosa ${ }^{I I}$
}

\section{ABSTRACT}

The essential oil plants contents can be affected by several factors. For example, in certain plants, collection time has been observed to affect the content and chemical composition of the essential oil obtained from the plant. The objective of this study was to evaluate the effect of collection time on the content and chemical composition of the essential oil from guava (Psidium guajava L.) leaves. Leaves were collected at different times of the day and the content and chemical composition of their essential oil was determined. Collection time did not qualitatively affect the chemical composition of the essential oil. However, concentration of certain substances in the oil, such as $\alpha$-humulene and trans-caryophyllene, did significantly vary at different collection times. The main constituents of the essential oil of Psidium guajava are limonene (2.2$4.4 \%)$, trans-caryophyllene (18.1-17.1\%), $\alpha$-humulene (26.3$20.4 \%)$, aromadendrene (7.6-12.2\%), $\alpha$-selinene (7.3-11.3\%), caryophyllene oxide (3.7-3.3\%), humulene epoxide II (4.1-1.9\%),

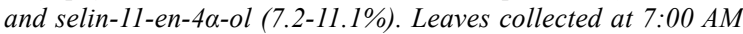
had higher essential oil production, with a content of $0.38 \%$ (d.b.), whereas leaves collected at 7:00 PM had lower essential oil production, $0.24 \%$ (d.b.). Chemical analysis showed that sesquiterpene compounds represented the highest concentration $(62.0 \%)$, and monoterpenoids and monoterpenes represented the lowest concentrations (1.1 and 2.2\%, respectively). Chemical classes that underwent major changes with respect to collection time were monoterpenes, sesquiterpenes, and sesquiterpenoids $(2.2-4.4 \%, 63.8-61.7 \%$, and $15.9-13.2 \%$, respectively).

Key words: Psidium guajava L., medicinal plants, special metabolites, $\alpha$-humulene, trans-caryophyllene, guava.

RESUMO

Existem fatores que podem afetar o conteúdo de óleo essencial das plantas, sendo o horário de coleta um deles.
Assim, observa-se que o teor e a composição química de óleo essencial podem variar em certas plantas de acordo com horário de coleta. O objetivo deste trabalho foi avaliar o efeito do horário de coleta sobre o conteúdo e a composição química do óleo essencial das folhas de goiabeira (Psidium guajava). Folhas de Psidium guajava foram coletadas em diferentes horários do dia para determinar teor e composição química de seu óleo essencial. $O$ óleo essencial não apresentou variação qualitativa da composição química em relação ao horário de coleta das folhas de Psidium guajava, mas alterou a concentração das substâncias, entre elas o a-humuleno e o trans-cariofileno. Os constituintes principais do óleo essencial das folhas de Psidium guajava são o limoneno (2,2-4,4\%), trans-cariofileno (18,1$17,1 \%)$, $\alpha$-humuleno $(26,3-20,4 \%)$, aromadendreno $(7,6-12,2 \%)$, a-selineno (7,3-11,3\%), óxido de cariofileno (3,7-3,3\%) epóxido de humuleno II $(4,1-1,9 \%)$ e o selin-11-en-4 $\alpha$-ol $(7,2-11,1 \%)$. No entanto, a maior produção de óleo essencial, foi obtida com as folhas coletadas às $19 \mathrm{~h}$, apresentando conteúdo de $0,38 \%$ (b.s.) e a mais baixa produção às $07 h$, apresentando conteúdo de $0,24 \%$ (b.s.). Através da análise química, identificou-se que compostos sesquiterpênicos apresentaram uma maior concentração $(62,0 \%)$ e os monoterpenos e monoterpenoides foram os que apresentaram menor concentração (2,2 e 1,1\%, respectivamente). As classes que sofreram maiores mudanças em relação ao horário de coleta foram os monoterpenos $(2,2-4,4 \%)$ e os sesquiterpenos e os sesquiterpenoides (63,8-61,7\% e 15,9-13,2\%, respectivamente).

Palavras-chave: Psidium guajava L., plantas medicinais, metabólitos especiais, $\alpha$-humuleno, trans-cariofileno, goiaba.

\section{INTRODUCTION}

The guava tree (Psidium guajava L.) belongs to the family Myrtaceae. It is considered to

\footnotetext{
Instituto Federal Goiano (IFG), Campus Rio Verde, 75901-970, Rio Verde, GO, Brasil. E-mail: elizabethjosefi@yahoo.com.br. ${ }^{*}$ Corresponding author.

"Laboratório de Análise e Síntese de Agroquímicos (LASA), Departamento de Química, Universidade Federal de Viçosa (UFV), Viçosa, MG, Brasil. 
be a native Mexican plant, but has spread throughout South America, Europe, Africa, and Asia (SHAH et al., 2011). Because it adapts to different climate conditions, it grows in all tropical and subtropical regions of the world; however, it is widespread in Brazil (GUTIÉRREZ et al., 2008; ROZANE, 2009). Studies characterizing the essential oil derived from guava leaves have shown the presence of 1,8-cineol, $\mathrm{d}$-limonene, and $\alpha$-pinene, important compounds with potential use as an insecticide (LIMA et al., 2009). Flavonoids, which possess strong antibacterial activity, have also been detected in guava extract (GUTIÉRREZ et al., 2008). Guava is widely used in folk medicine, and data published in the literature showed that extracts obtained from its leaves possess hepatoprotective, antiinflammatory, antioxidant, antinociceptive, antidiabetic, and other properties (BEATRIZ, et al., 2012). Guava is also used for the treatment of diarrhea and dysentery due to its antispasmodic and antimicrobial properties, which have supported its long-standing use in traditional medicine (BEATRIZ, et al., 2012).

Among secondary metabolites produced by plants, essential oils are of particular importance. They are responsible for the typical smell and flavor of a plant, but are also directly related to attraction of pollinators, protection from insects, and several other functions necessary for plant survival. Essential oils have an extremely complex chemical composition that includes volatile, lipophilic, aromatic, and liquid substances. They are referred as oils due to their oily appearance at room temperature. In medicinal and aromatic plants, terpenes and terpenoids are the most frequent substances (RIBEIRO et al., 2012).

In medicinal plants, growth and development dynamics and changes in phenological phase can cause biochemical and physiological alterations that are capable of changing the production of biologically active substances. By affecting the qualitative and quantitative aspects of these substances, such changes directly influenced the content and quality of essential oils (TAIZ; ZEIGER, 2004, EHLERT et al., 2013). Environmental factors such as photoperiod, temperature, humidity, precipitation, soil conditions, and intensity of solar radiation can also influence the biosynthesis of essential oils. Secondary metabolism is known for showing response patterns related to environmental stimuli, and it is thought that increased concentrations of active ingredients might establish a connection between the environmental temperature and metabolic activity of the plant (BLANK et al., 2005). Temperature and luminosity varies throughout the day, which can alter the quantity and chemical composition of essential oil (PAULUS et al., 2013). Therefore, identifying the best time to carry out the collection and the time when production of the essential oil by medicinal plants is higher, is important with regard to production of these special metabolites (PAULUS et al., 2013, MIRANDA et al., 2013).

To increase the potential for biological activity in medicinal plants, it is necessary to understand how content and chemical composition of the essential oil change in relation to the time the vegetable material is collected, as well as any other factors that might affect production and quality. Therefore, the aim of this study was to assess the influence of the collection time of leaves from guava trees on the content and their essential oil chemical composition they contain.

\section{MATERIALS AND METHODS}

\section{Vegetable material}

The experiment was performed at the Goiano Federal Institute, Rio Verde - GO Campus, in the Laboratory of Natural Products Chemistry. In March 2014, fresh Psidium guajava leaves were collected between 7:00 AM and 7:00 PM from a native population in the Rio Verde region. Collection occurred at coordinates $17^{\circ} 48^{\prime} 12.006^{\prime \prime} \mathrm{S}$ and $50^{\circ} 54^{\prime} 19.083^{\prime \prime} \mathrm{W}$, at an altitude of 715 meters. Vegetable material was identified, and the samples were deposited as desiccated specimens in the Herbarium of the State University of Montes Claros in Minas Gerais, under identification number 4481. A randomized experimental design was used, with five different harvest times: 7:00 AM (T1), 10:00 AM (T2), 1:00 PM (T3), 4:00 PM (T4), and 7:00 PM (T5), defined according to previous tests. For each treatment were collected six sets of samples. Leaves collected were analyzed in the Laboratory of Natural Products Chemistry at the Rio Verde - GO campus of Goiano Federal Institute. Meteorological data was obtained from the INMET/Rio Verde University weather station.

\section{Essential oil extraction}

At each collection time, $600 \mathrm{~g}$ of vegetable material was collected to assess the content of the essential oil, with $100 \mathrm{~g}$ used for each repetition. The vegetable material was collected from three large, adult Psidium guajava plants, with samples taken from the bottom, middle, and upper parts of the plant, including both new and mature leaves. The collected biomass was homogenized, and then extracted through the hydro distillation method (1L of distilled water) 
for $2 \mathrm{~h}$, using a Clevenger-type apparatus. Afterwards, the essential oil was extracted from the aqueous phase using a partition with the organic solvent dichloromethane $(3 \times 10 \mathrm{ml})$. It was then dehydrated with anhydrous sodium sulfate, concentrated, weighed with an analytical scale, and stored at $4^{\circ} \mathrm{C}$ until further analysis of its chemical composition.

\section{Chemical analysis of the essential oils}

Essential oil chemical composition was analyzed in the Laboratory of Analysis and Synthesis of Agrochemicals at the Federal University of Viçosa, located in Viçosa, state of Minas Gerais (MG). Quantitative analysis of the essential oil components was performed in a Shimadzu GC-17A gas chromatograph equipped with a flame ionization detector (FID) and SPB-5 fused silica capillary column $(30 \mathrm{~m} \times 0.25 \mathrm{~mm}$ with a film thickness of $0.25 \mu \mathrm{m})$. Nitrogen was used as the carrier gas $\left(1.8 \mathrm{~mL} \mathrm{~min}^{-1}\right)$, split $1 / 10$, and injector and detector temperatures were 220 and $240^{\circ} \mathrm{C}$, respectively. Initial column temperature was $40^{\circ} \mathrm{C}$ isothermal for 4 minutes, followed by heating at $3^{\circ} \mathrm{C}$ $\min ^{-1}$ until $240^{\circ} \mathrm{C}$ was reached; $1 \mu \mathrm{L}$ of the essential oil was injected for the respective analysis.

To identify the components of the essential oils, a gas chromatograph was used (CG-EM Shimadzu, QP-5050A). It was equipped with a mass-selective detector, operating by electronic ionization $(70 \mathrm{eV})$, with an RTX-5 fused silica column $(30 \mathrm{~m} \times 0.25 \mathrm{~mm}$ with a film thickness of $0.25 \mu \mathrm{m})$. Chromatographic conditions were identical to the conditions applied to the CG-FID, except for the carrier gas, which in this case was helium at a $1 \mathrm{~mL} \mathrm{~min}^{-1}$ flow. Components were identified by comparing the obtained mass spectra to the records of the $7^{\text {th }}$ edition of the Wiley computational library. Components were also identified using temperature and calculation programming, calculating the linear retention index (LRI) according to the method described by Van den DOOL \& KRATZ (1963).

\section{Oil content and chemical composition}

The percentage content of essential oil was calculated for samples from each collection time using the following formulas: $\mathrm{T} \%=[$ Oil mass $(\mathrm{g}) / 100 \mathrm{~g}] \times 100$ for the humid base $(\mathrm{hb})$ and $\mathrm{T} \%=$ [Oil mass $(\mathrm{g}) / 36.6 \mathrm{~g}] \times 100$ for the dry base $(\mathrm{db})$. The mass of $36.6 \mathrm{~g}$ was obtained by drying the leaves in a greenhouse at $40^{\circ} \mathrm{C}$, with forced air circulation, until stable mass was obtained for each sample.

Statistical analysis

The data were subjected to a variance analysis and the averages were compared at $5 \%$ probability using the SISVAR - Variance analysis system software (FERREIRA, 2007).

\section{RESULTS AND DISCUSSION}

\section{Essential oil content}

Essential oils extracted from fresh and dried leaves of Psidium guajava had a slightly yellow color, with a pleasant smell typical of the plant. The time at which the guava tree leaves were collected significantly influenced the content and moisture of the essential oil (Table 1). The humidity content in the leaves varied between 57.6 and 54.4\% during the day. These values were obtained from the first (7:00 AM) and last collection of the day (7:00 PM), respectively. Time of leaves collection also influenced the oil content, which showed anincrease through the day. The lowest yield was obtained from the first collection of the day (7:00 AM, 0.24\% $\mathrm{db}$ ), and the highest yield was obtained at 7:00 PM $(0.38 \% \mathrm{db})$, the last collection of the day.

These results suggested the need to perform specific studies for each species, hindering the ability to define a standard procedure for production of essential oils in aromatic plants (OLIVEIRA et al., 2012). According to MELO et al. (2011), essential oil content is directly influenced by the oscillation of temperature and humidity throughout the day. Therefore, knowing the ideal time to plant material collection for a higher yield of the desired active ingredient is extremely important, especially for treatment and managements of cultivation of these plants, reinforcing the importance of secondary metabolic response in relation to the plant environment.

\section{Chemical composition}

The essential oil obtained from Psidium guajava leaves did not show any qualitative variation in the chemical components in relation to the collection time. However, their quantitative composition varied significantly (Table 2). Analysis of the oil's chemical composition identified 17 components present at each of the different collection times. From the first collection to the last collection, the concentrations of monoterpenes, monoterpenoids, sesquiterpenes, and sesquiterpenoids varied from $2.2 \%$ to $4.4 \%, 1.0 \%$ to $1.2 \%, 63.8 \%$ to $61.7 \%$, and $15.9 \%$ to $13.2 \%$, respectively.

The main components of the essential oil were limonene $(2.2 \%)$, trans-caryophyllene $(17.1 \%), \quad \alpha$-humulene $(16.2 \%)$, aromadendrene (12.2\%), $\alpha$-selinene (11.3\%) caryophyllene oxide 
Table 1 - Essential oil concentration and moisture of guava tree leaves (Psidium guajava) collected at different times of the day in the Goiano Federal Institute, Rio Verde - GO Campus, 2014.

\begin{tabular}{lccc}
\hline Collection time & Concentration of essential oil in hb ${ }^{*}(\%)$ & Concentration of essential oil in db ${ }^{* *}(\%)$ & Humidity content $(\%)$ \\
\hline $7: 00 \mathrm{AM}$ & $0.09^{\mathrm{C}}$ & $0.24^{\mathrm{C}}$ & $57.64^{\mathrm{A}}$ \\
$10: 00 \mathrm{AM}$ & $0.10^{\mathrm{CB}}$ & $0.27^{\mathrm{C}}$ & $56.30^{\mathrm{B}}$ \\
$1: 00 \mathrm{PM}$ & $0.11^{\mathrm{CBA}}$ & $0.30^{\mathrm{B}}$ & $56.29^{\mathrm{B}}$ \\
$4: 00 \mathrm{PM}$ & $0.12^{\mathrm{BA}}$ & $0.33^{\mathrm{AB}}$ & $54.62^{\mathrm{C}}$ \\
$7: 00 \mathrm{PM}$ & $0.14^{\mathrm{A}}$ & $0.38^{\mathrm{A}}$ & $54.51^{\mathrm{C}}$ \\
& $\mathrm{CV}: 13.85 \%$ & $\mathrm{CV}: 4.58 \%$ & $\mathrm{CV}: 0.46 \%$
\end{tabular}

Measurements followed by the same letter are not statistically different among themselves at 5\% probability level according to the Tukey's tests; ${ }^{*}$ hb - humid base; ${ }^{* *} \mathrm{db}-$ dry base.

(3.8\%), humulene epoxide II $(2.6 \%)$, and selin-11en-4 $\alpha$-ol $(9.9 \%)$. Collection time did influence the concentrations of these components. The largest percentages of $\alpha$-humulene and trans-caryophyllene, the components of the oil with the highest concentrations, were found in leaves collected at 7:00 AM; the lowest percentages occurred in leaves collected between 1:00 PM and 4:00 PM. For trans- caryophyllene, $\alpha$-humulene, and humulene epoxide II, the highest concentrations occurred early in the day at 7:00 AM. Caryophyllene oxide had its highest concentration between 10:00 AM and 4:00 PM, $\alpha$-selinene and aromadendrene had their highest concentration between 1:00 PM and 4:00 PM, and selin-11-en-4 $\alpha$-ol had its highest concentration between 4:00 PM and 7:00 PM. The highest limonene

Table 2 - Chemical composition of the essential oil from guava tree leaves (Psidium guajava) collected at different times in the Instituto Federal Goiano, Rio Verde - GO Campus, in March 2014. The components are listed according to the order of elution from an RTX-5 column.

\begin{tabular}{|c|c|c|c|c|c|c|}
\hline \multirow{2}{*}{ COMPONENT } & \multirow{2}{*}{$\mathrm{RI}^{*}$} & \multicolumn{5}{|c|}{--Collection time (\%)- } \\
\hline & & 7:00 AM & 10:00 AM & 1:00 PM & 4:00 PM & 7:00 PM \\
\hline limonene & 1024 & 2.2 & 1.4 & 1.3 & 1.8 & 4.4 \\
\hline 1,8-cineol & 1026 & 1.0 & 1.0 & 1.1 & 1.2 & 1.2 \\
\hline$\alpha$-copaene & 1374 & 1.0 & 1.3 & 1.3 & 1.3 & 1.2 \\
\hline trans-caryophyllene & 1419 & 18.1 & 17.7 & 16.9 & 16.1 & 16.6 \\
\hline$\alpha$-humulene & 1454 & 26.3 & 13.8 & 8.6 & 11.9 & 20.4 \\
\hline 4,11-selinadiene & 1475 & 1.1 & 1.3 & 1.3 & 1.3 & 1.2 \\
\hline$\gamma$-muurolene & 1478 & 0.8 & 1.2 & 1.4 & 1.4 & 1.0 \\
\hline aromadendrene & 1488 & 7.6 & 13.2 & 15.3 & 14.7 & 10.1 \\
\hline$\alpha$-selinene & 1497 & 7.3 & 12.0 & 14.0 & 13.6 & 9.5 \\
\hline$\alpha$-panasinsene & 1517 & 1.2 & 1.3 & 1.2 & 1.3 & 1.3 \\
\hline trans-nerolidol & 1566 & 3.3 & 3.4 & 3.2 & 3.3 & 3.8 \\
\hline caryophyllene oxide & 1585 & 3.7 & 4.2 & 3.6 & 4.1 & 3.3 \\
\hline humulene epoxide II & 1612 & 4.1 & 2.1 & 3.4 & 1.4 & 1.9 \\
\hline longipinene epoxide & 1620 & 1.6 & 1.0 & 1.3 & 1.8 & 1.0 \\
\hline epi- $\alpha$-muurolol & 1639 & 2.9 & 3.8 & 2.9 & 4.0 & 3.0 \\
\hline$\alpha$-cadinol & 1651 & 0.7 & 1.2 & 0.9 & 1.6 & 1.3 \\
\hline selin-11-en- $4 \alpha$-ol & 1662 & 7.2 & 10.8 & 8.0 & 12.5 & 11.1 \\
\hline Total identified & & 91.0 & 91.5 & 86.6 & 94.1 & 93.2 \\
\hline Hydrocarbons monoterpenes (HM) & & 2.2 & 1.4 & 1.3 & 1.8 & 4.4 \\
\hline Oxygenated monoterpenes (OM) & & 1.0 & 1.0 & 1.1 & 1.2 & 1.2 \\
\hline Hydrocarbons sesquiterpenes (HS) & & 63.8 & 62.2 & 60.5 & 62.0 & 61.7 \\
\hline Oxygenated sesquiterpenes (OS) & & 15.9 & 14.7 & 14.6 & 14.8 & 13.2 \\
\hline
\end{tabular}

RI*: experimental retention index using an RTX-5 column. Number of injections per sample: 5 . Standard deviation: \pm 0.35

Ciência Rural, v.46, n.10, out, 2016. 
content was obtained from leaves collected at 7:00 PM. The lowest amounts of $\alpha$-selinene and selin-11en-4 $\alpha$-ol were found in leaves collected at 7:00 PM. For limonene and $\alpha$-humulene, the lowest amounts occurred at 1:00 PM, and for trans-caryophyllene and humulene epoxide II, the lowest amounts were found at 4:00 PM. For caryophyllene oxide and aromadendrene, the lowest concentrations were found at 7:00 PM. The minor components did not show great variation in their content.

While studying the influence of time of collection on chemical composition of the essential oil from different aromatic species, authors such as BLANK et al. (2005), EHLERT et al. (2013), and OLIVEIRA et al. (2012) noticed variation in their chemical composition. SILVA et al. (2003b) studied these parameters for Ocimum basilicum, but did not observe any variation in the chemical composition of the essential oil at different times of the day.

The influence of the time that vegetable material is collected on the concentration of chemical components in the essential oil can affect biological activity and pharmacological applications. For example, $\alpha$-humulene and transcaryophyllene are the components with the highest concentration in essential oil from guava tree leaves. Because these components have biological potential, determining the best collection time is important to obtain the highest yield of the desired metabolites (FERNANDES et al., 2007). Results of this study show that the maximum concentration of these two components can be obtained by performing leaves collection earlier in the day.

Because the concentrations of compounds change during the day, to identify the best time to collect from a medicinal or aromatic species, it is important to consider which components need to be collected in higher amounts.

\section{CONCLUSION}

The essential oil obtained from Psidium guajava consists of monoterpenes, monoterpenoids, sesquiterpenes, and sesquiterpenoids. Sesquiterpenes constitute the largest fraction, and monoterpenes and monoterpenoids constitute the smallest fraction. Taking into consideration that the circadian assessment was performed for only one day, the study reported that the highest essential oil content could be obtained at 7:00 PM $(0.38 \% \mathrm{db})$, and the lowest at 7:00 AM $(0.24 \% \mathrm{db})$. It was also reported that concentrations of the chemical components in the essential oil from Psidium guajava leaves can vary, with the highest variation occurring in the main components, trans-caryophyllene $(18.1 \%$ and $17.1 \%$ at 7:00 AM and 7:00 PM, respectively) and $\alpha$-humulene $(26.3 \%$ and $20.4 \%$ at $7: 00$ AM and 7:00 PM, respectively).

The results obtained in this study can be associated with several factors that might influence the biosynthesis of secondary metabolites, including availability of water, amount of light, and predator attacks, among others. When these phenomena occur, the concentration of essential oils is usually higher, making it the most appropriate time to collect the vegetable material (EHLERT et al., 2013).

\section{ACKNOWLEDGEMENTS}

The authors would like to thank Coordenação de Aperfeiçoamento de Pessoal de Nível Superior (CAPES) for the financial support offered through a scholarship. The Instituto Federal Goiano, Rio Verde Campus for making their infrastructure available, and the Laboratory of Analysis and Synthesis of Agrochemicals of the Universidade Federal de Viçosa for collaborating on the analysis of the chemical components of the essential oils.

\section{REFERENCES}

BEATRIZ, P. M. et al. Antifungal activity of Psidium guajava organic extracts against dermatophytic fungi. Journal of Medicinal Plants Research, v.6, n.41, p.5435-5438, 2012. Available from: <http://academicjournals.org/journal/JMPR/ article-abstract/8AD03FC21782>. Accessed: Ago. 10, 2014. doi: $10.5897 /$ JMPR12.240.

BLANK, A. F. et al. Harvest time of influence and leaves drying in the essential oil of lemon balm (Melissa officinalis L.) grown in two. Journal of Medicinal Plants, v.8, n.1, p.73-78, 2005. Available from: <http://www.sbpmed.org.br/download/issn_05_4/ artigo14_v8_n1.pdf $>$. Accessed: Ago. 18, 2014.

DE MELO, M. T. P. et al. Teor de óleo essencial de alecrimpimenta em função do horário de colheita. Ciência Rural, v.41, n.7, p.1166-1169, 2011. Available from: <http:/www.scielo.br/ scielo.php?script $=$ sci_arttext\&pid $=$ S0 1038478201100070001 0\&lng=pt\&nrm=iso\&tlng=pt $>$. Accessed: Ago. 25, 2014. doi: 10.1590/S0103-84782011000700010.

EHLERT, P. A. D. et al. Influência do horário de colheita sobre o rendimento e composição do óleo essencial de ervacidreira brasileira [Lippia alba (Mill.) N. E. Br.]. Revista Brasileira Plantas Medicinais, v.15, n.1, p.72-77, 2013. Available from: <http://www.scielo.br/scielo.php?pid=S151605722013000100010\&script $=$ sci_arttext $>$. Accessed: Ago. 22, 2014. doi: 10.1590/S1516-05722013000100010.

FERREIRA, DF. SISVAR: sistema de análise de variância para dados balanceados. Lavras: DEX/UFLA, 2007. Versão 5.1 Build 72.

FERNANDES, S. E. et al. Os efeitos anti-inflamatórios dos compostos de alfa-humuleno e (-) - trans-cariofileno isolados 
a partir do óleo essencial de Cordia verbenácea. European Journal of Pharmacology, v.569, n.3, p.228-236, 2007. Available from: <http://www.sciencedirect.com/science/article/ pii/S0014299907005419>. Accessed: Ago. 28, 2014. doi: 10.1016/j.ejphar.2007.04.059.

GUTIÉRREZ, R. M. P. et al. Psidium guajava: a review of its traditional uses, phytochemistry and pharmacology. Journal of Ethnopharmacology, v.117, p.1-27, 2008. Available from: $<$ http:// www.sciencedirect.com/science/article/pii/S0378874108000536>. Accessed: Ago. 25, 2014. doi: 10.1016/j.jep.2008.01.025.

LIMA, R. K. et al. Essential oil chemical composition from leaves of guava (Psidium guajava L.) and its effects on the fall armyworm Spodoptera frugiperda (J. E. Smith, 1797). (Lepidoptera: Noctuidae) behavior. Ciência e agrotecnologia, v.33, Ed. Esp, p.1777-1781, 2009. Available from: $\quad<$ http://www.scielo.br/scielo.php?pid=S1413$70542009000700013 \&$ script $=$ sci_arttext $>$. Accessed: Ago. 25, 2014. doi: 10.1590/S1413-70542009000700013.

MIRANDA, V. C. et al. Evaluation of the effect of time of cutting on the content of the essential oil of the holy grass (Cymbopogon citratus (DC) Stapf). Journal of Biotechnology and Biodiversity, v.4, n.1, p.55-59, 2013. Available from: <http://revista.uft.edu.br/index.php/JBB/ article/viewFile/430/285>. Accessed: Ago. 20, 2014.

OLIVEIRA, A. R. M. F. et al. Determinação do tempo de hidrodestilação e do horário de colheita no óleo essencial de menta. Horticultura Brasileira, v.30, p.155-159, 2012. Available from: <http://www.scielo.br/scielo.php?pid=S010205362012000100026\&script $=$ sci arttext $>$. Accessed: Sept. 01, 2014. doi: 10.1590/S0102-05362012000100026.
PAULUS D. et al. Teor e composição química de óleo essencial de cidró em função da sazonalidade e horário de colheita. Horticultura brasileira, v.31, n.2, p.203-209, 2013. Disponível em: <http://www.scielo.br/scielo.php?pid=S0102$05362013000200005 \&$ script $=$ sci arttext $>$. Accessed: Ago. 28, 2014. doi: 10.1590/S0102-05362013000200005.

RIBEIRO, D. S. et al. Avaliação do óleo essencial de alecrim (Rosmarinus officinalis L.) como modulador da resistência bacteriana. Semina: Ciências Agrárias, v.33, n.2, p.687-696, 2012. Available from: <http://www.uel.br/revistas/uel/index.php/ semagrarias/article/view/7496>. Accessed: Ago. 31, 2014. doi: 10.5433/1679-0359.2012v33n2p687.

ROZANE, D. E. et al. Cultura da goiabeira do plantio a comercialização. Jaboticabal: FUNDUNESP \& SBF, 2009. p. $407-428$

SHAH, A. J. et al. Pharmacological basis for the medicinal use of Psidium guajava leave in hyperactive gut disorders. Bangladesh Journal Pharmacology, v.6, p.100-105, 2011. Available from: <http://www.banglajol.info/index.php/BJP/ article/viewFile/8692/6722>. Accessed: Ago. 28, 2014. doi: 10.3329/bjp.v6i2.8692.

TAIZ, L.; ZEIGER, E. Fisiologia vegetal. Porto Alegre: Artmed, 2004. 719p.

VAN DEN DOOL, H.; KRATZ, P. D. A generalization of the retention Indexx system including linear temperature programmed gas-liquid partition chromatography. Journal of Chromatography A, v.11, p.463-471, 1963. Available from: <http://www. sciencedirect.com/science/article/pii/S002196730180947X $>$. Accessed: Jun. 19, 2015. doi: 10.1016/S0021-9673(01)80947-X. 